\title{
Migrating Foreign Body Bronchus: An Unusual Case of Foreign Body Aspiration
}

\author{
Ram Badan Singh1, Ajay Narayan Gangopadhyay², Dinesh Kumar Gupta2, \\ Vaibhav Pandey ${ }^{*}$ \\ ${ }^{1}$ Department of Anaesthesia, Institute of Medical Sciences, Banaras Hindu University, Varanasi, India \\ ${ }^{2}$ Department of Paediatric Surgery, Institute of Medical Sciences, Banaras Hindu University, Varanasi, India \\ Email: rambadan.vns@gmail.com, gangulybhu@rediffmail.com, hodps@rediffmail.com, \\ sunny.imsbhu@gmail.com
}

Received 23 April 2014; revised 22 May 2014; accepted 21 June 2014

Copyright (C) 2014 by authors and Scientific Research Publishing Inc.

This work is licensed under the Creative Commons Attribution International License (CC BY).

http://creativecommons.org/licenses/by/4.0/

(c) (i) Open Access

\begin{abstract}
Foreign bodies [FB] in the bronchus are important causes of morbidity and mortality in paediatric age group and pose diagnostic and therapeutic challenges. Inert and smooth foreign bodies are prone for migration from one side to other due to minimal inflammatory process and easy mobility. Herein we are reporting a case of electric bulb aspiration which migrated from right main bronchus to left main bronchus.
\end{abstract}

\section{Keywords}

Foreign Body, Aspiration, Bulb Aspiration, Migrating Foreign Body

\section{Introduction}

Foreign bodies [FB] in the bronchus are important causes of morbidity and mortality in paediatric age group and pose diagnostic and therapeutic challenges [1] [2]. The list of foreign bodies aspirated is endless from nuts, seeds to sharp, metallic objects such as needles, toothpicks [3]. The clinical presentation depends on site, nature, age of patient and duration [4]. Herein we report a case of foreign body aspiration presenting with unusual presentation and complicated management.

\section{Case}

A 4-year-old boy was presented with recurrent cough and fever for 3 months. There was no history of weight

${ }^{*}$ Corresponding author.

How to cite this paper: Singh, R.B., Gangopadhyay, A.N., Gupta, D.K. and Pandey, V. (2014) Migrating Foreign Body Bronchus: An Unusual Case of Foreign Body Aspiration. Case Reports in Clinical Medicine, 3, 407-409.

http://dx.doi.org/10.4236/crcm.2014.37090 
loss and night sweats. The child had received multiple courses of antibiotic therapy with the diagnosis of bacterial pneumonia. The symptoms had become much worse over the period of the last one month before she attended to our hospital. On physical examination, child was tachypnic with respiratory rate $34 / \mathrm{min}$, right side chest movement was restricted with decreased breath sounds and fine crepts. Rest of systemic examination was unremarkable. Roentgenograms of the chest (Postero-anterior and lateral view) showed presence of electric bulb with filament in the right bronchus (Figure 1). Intravenous Amoxicillin-clavulunate $(100 \mathrm{mg} / \mathrm{kg} / \mathrm{day}$ in three divided doses), Amikacin (15 mg/kg/per dose in two divided doses) and metronidazole $(7.5 \mathrm{mg} / \mathrm{kg} / \mathrm{dose}$, three doses per day) were started and child was taken up for rigid bronchoscopy. On bronchoscopy there was significant mucus accumulation and inflammation on right side but no foreign body was visualised. On examination of left bronchus electric bulb body was found in left lower lobe bronchus (Figure 2).

\section{Discussion}

Foreign body inhalation is common worldwide [1]. Children aged between 1 and 5 years of age are commonly affected [2] [3]. Overactive nature of male babies as compared to the females may be attributed to male preponderance [5]. X-ray evaluation is indicated for all patients in whom an esophageal FB is suspected [6]. However, a negative radiographic result does not exclude the presence of foreign bodies in the aerodigestive tract as radio-lucent objects like rubber materials, groundnuts and bolus of meat are not easily detected by plain radiography. Chest radiographs are commonly performed in children with suspected FBA. Chest radiographs may show unilateral lobar hyperlucency, localized atelectasis, and localized pulmonary infiltrate. However, a normal radiograph cannot exclude FBA [7]. In undetected cases, computed tomography (CT) scanning should be done [7]. Foreign body migration has been previously reported [8]. The mechanism of migration is due to high flow generated by coughing [9]. Inorganic and smooth foreign bodies are more likely to migrate [8]-[10]. Our case was

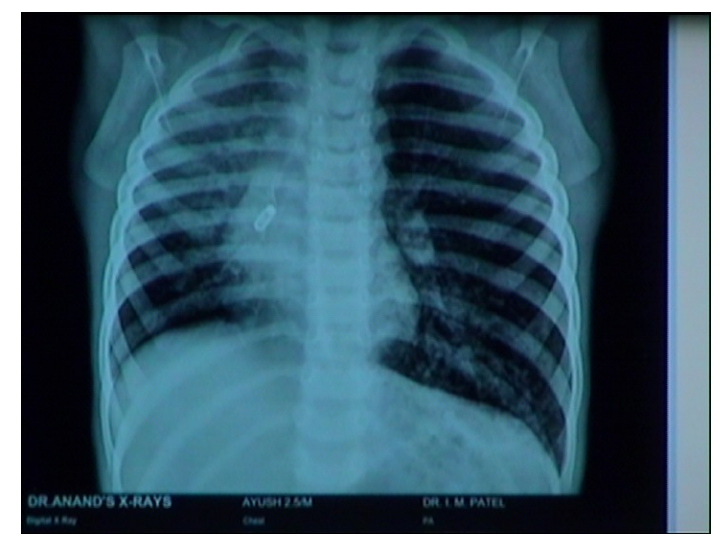

Figure 1. Radiograph showing electric bulb in right bronchus.

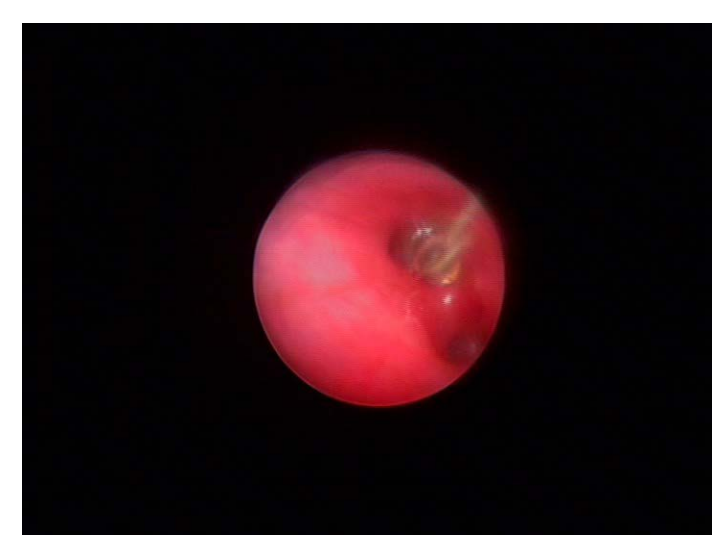

Figure 2. Electric bulb in left bronchus. 
an electric bulb with smooth surface which predisposed its migration. Endoscopic removal of foreign bodies in the aerodigestive tract using rigid scopes under general anaesthesia has been reported to be a golden standard procedure [11]. This is both a diagnostic and a management method and is generally recommended for most patients with history of FB ingestion. Rigid endoscopy, as compared to flexible endoscopy is a useful method to diagnose and remove foreign bodies in the aerodigestive tract as it has a large lumen and allows better visualization of the potential anatomic sites of foreign body impaction in the aerodigestive tract [12]. Foreign body aspiration is a common medical emergency with serious airway obstruction and sudden respiratory distress occurs immediately in complete obstruction. If the obstruction is incomplete foreign body becomes lodged, progressive respiratory symptoms such as chronic cough, wheezing, hemoptysis, pneumonia and atelectasis can develop and the diagnosis is usually delayed.

\section{Conclusion}

We hypothesise that inert and smooth foreign bodies in the bronchus are prone for migration from one side to other due to minimal inflammatory process and easy mobility. A high index of suspicion of migration is required if foreign body is not localised intraoperatively.

\section{References}

[1] James, B. and Snow, J.R. (1991) Bronchology. In: Colman, B.H., Ed., Disease of the Nose, Throat, Ear, Head and Neck, 14th Edition, Churchill Livingstone, 1278-1296.

[2] Rothman, B.F. and Boeckman, C.R. (1980) Foreign Bodies in the Larynx and Tracheobronchial Tree in Children. A Review of 225 Cases. Annals of Otology, Rhinology Laryngology, 89, 434-436.

[3] Karakoc, F., Karadag, B., Akbenlioğlu, C., Ersu, R., Yildizeli, B., Yuksel, M. and Dagli, E. (2002) Foreign Body Aspiratin: What Is the Outcome? Pediatric Pulmonology, 34, 30-36. http://dx.doi.org/10.1002/ppul.10094

[4] Yamamoto, S., Suzuld, K., Itaya, T., Yamamoto, E. and Baba, S. (1996) Foreign Bodies in the Airway. Eighteen Years Retrospective Study. Acta Otolaryngologica (Suppl Stock), 525, 6-8.

[5] Rovin, J.D. and Rodger, M.B. (2000) Paediatric Foreign Body Aspiration. Paediatric Review, 21, 86-90.

[6] Schmidt, H. and Manegold, B.C. (2000) Foreign Body Aspiration in Children. Surgical Endoscopy, 14, 644-648. http://dx.doi.org/10.1007/s004640000142

[7] Berger, P.E., Kuhn, J.P. and Kuhns, L.R. (1980) Computed Tomography and the Occult Tracheobronchial Foreign Body. Radiology, 134, 133-135.

[8] Kikuchi, R., Isowa, N., Tokuyasu, H. and Kawasaki, Y. (2007) Intraoperative Migration of a Nail from the Left B 10b to the Main Bronchus. Interactive Cardiovascular and Thoracic Surgery, 6, 92-93. http://dx.doi.org/10.1510/icvts.2006.144683

[9] Wu, C.T. and Wang, C.J. (2006) Alternate Lung Collapse in a 9-Year-Old Boy with Peanut Aspiration. Pediatric Radiology, 36, 1327-1328. http://dx.doi.org/10.1007/s00247-006-0296-X

[10] Parray, T., Abraham, E., Apuya, J., Ghafoor, A. and Siddiqui, M. (2009) Migration of a Foreign Body from Right to Left Lung. The Internet Journal of Anesthesiology, 24.

[11] Mosca, S., Manes, G., Martino, R., et al. (2001) Endoscopic Management of Foreign Bodies in the Upper Gastrointestinal Tract: Report on a Series of 414 Adult Patients. Endoscopy, 33, 692-696. http://dx.doi.org/10.1055/s-2001-16212

[12] Janik, J.E. and Janik, J.S. (2003) Magill Forceps Extraction of Upper Esophageal Coins. Journal of Pediatric Surgery, 38, 227-229. http://dx.doi.org/10.1053/jpsu.2003.50049 
Scientific Research Publishing (SCIRP) is one of the largest Open Access journal publishers. It is currently publishing more than 200 open access, online, peer-reviewed journals covering a wide range of academic disciplines. SCIRP serves the worldwide academic communities and contributes to the progress and application of science with its publication.

Other selected journals from SCIRP are listed as below. Submit your manuscript to us via either submit@scirp.org or Online Submission Portal.
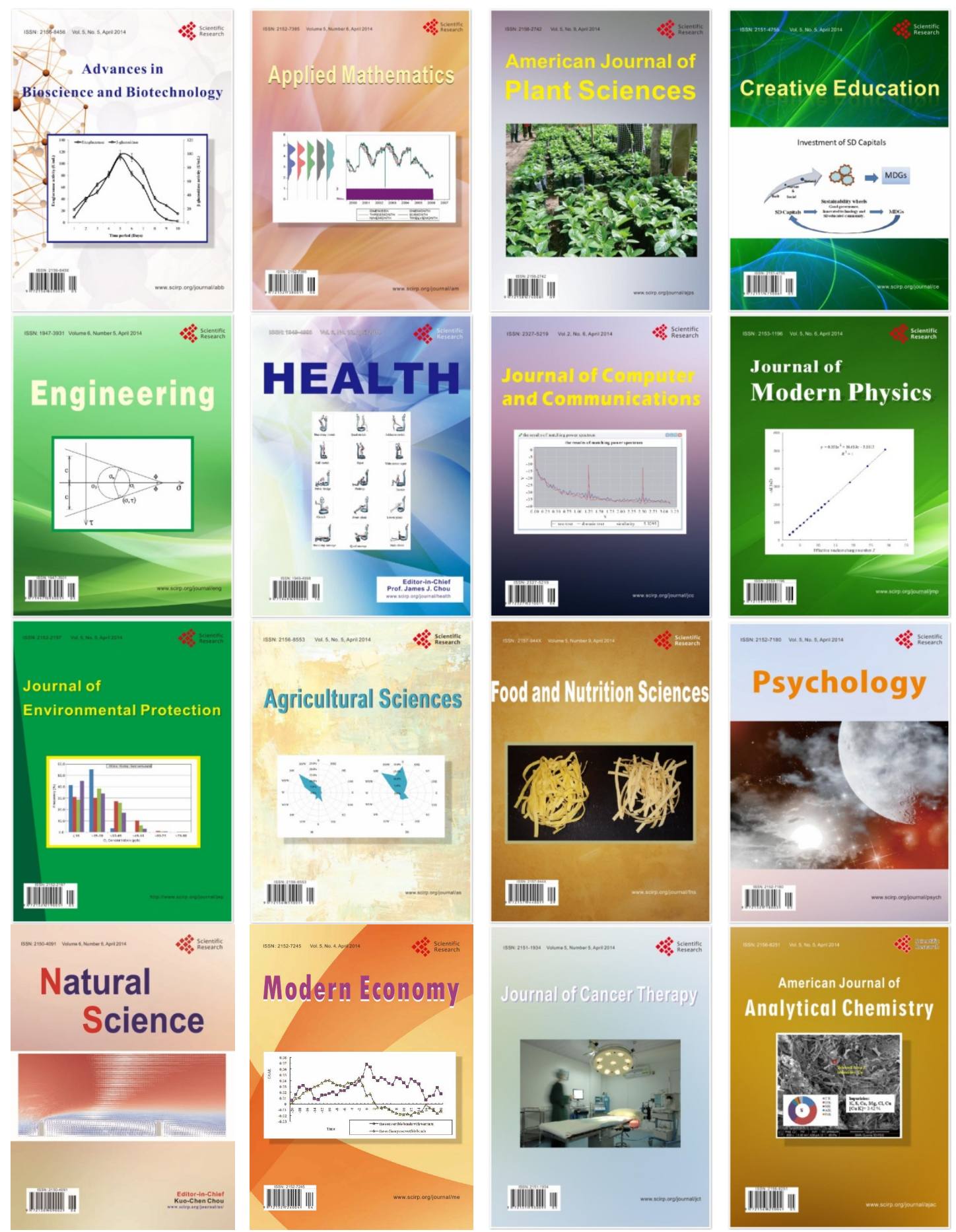